\title{
WATER BALANCE MODEL FOR PLANNING REHABILITATION OF A TANK CASCADE IRRIGATION SYSTEM IN SRI LANKA
}

Jun Itakura

\begin{abstract}
In May 1992, Jun Itakura started his work with IIMI as an Irrigation Specialist to carry out research studies on the improvement of water management in inter-connected tanks in the dry zone of Si Lanka. Mr. Itakura was seconded to IIMI for three years by the Government of Japan under the JICA-IIM! Collaborative Program. He has since returned to work with the Agriculture Improvement Bureau of the Ministry of Agriculture, Forestry and Fisheries in Japan.
\end{abstract}

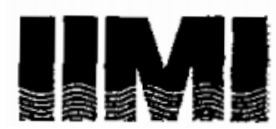

INTERNATIONAL IRRIGATION MANAGEMENT INSTITUTE 
Itakura, J. 1995. Water balance model for planning rehabilitation of a tank cascade irrigation system in Sri Lanka. Colombo, Sri Lanka: International Irrigation Management Institute (IIMI). iv, 61p. (IIMI working paper no.37)

Irrigation management/ Irrigation systems/ Wafer balance/ Simulation models/ Rehabilitation/ Agricultural production/ Watershed management/ Reservoirs/ Tank irrigation/ Thirappane/ Nachchaduwa/ Sri Lanka

DDC : 631.7

ISBN: 92-9090-320-1

IIMI's Working Paper series is intended to stimulate discussion among people interested in aspects of irrigation management. These papers make available the results of recent or ongoing research, and the informed opinions of IIMI staff members and collaborators, as early as possible. The views expressed are, therefore, those of the author and do not (at this stage) necessarily represent the consensus of IIMI or its partners. [IMI will welcome comments on this paper, which should be sent either to IIMI or to the author at the following address:

Information Office

International Irrigation Management Institute

P.O.Box 2075

Colombo

Sri Lanka

(C) IIM], 1995

All rights reserved. 


\section{Foreword}

Since time immemorial, people in South Asia have collected rainfall runoff in small storage reservoirs (called tanks) for later use in agricultural production, for domestic use and watering of livestock. A unique feature of the tanks in Sri Lanka is that often several of the tanks are linked together through a canal. The resulting cascade of tanks should then be managed as one system. The Thirappane cascade, which is the topic of this study, falls within the catchment area of a much bigger reservoir, Nachchaduwa. The latter was built around 900 AD, and restored in 1906, when many of the tanks still in use now were surveyed and restored to use. Cascade management, however, was not always carried out properly and restoration work not done, that the skills to do so were lost. The management of these interconnected tanks presents many interesting questions, the answers to which hitherto have not been fully explored. The effectiveness of storage-based irrigation systems was such that over time more and more people were attracted to the command areas of the tanks and many of the systems became unsustainable due to overcrowding.

The objective of this study was a limited one, i.e., to explore through simple water balance modelling several improved management options for a particular set of tanks in the Thirappane Cascade and to examine how the tank cascade can be stabilized through structural modifications. The water balance model developed for this purpose has deliberately been kept simple, requiring only data that can be easily collected in the field. As a result, the major constraint of the model is in the assumed static runoff coefficients, which are known to be deficient as runoff depends - among other things - on the soil moisture content when rainfall and runoff occur. Notwithstanding the limitations in the assumed nature of the coefficients employed in the water balance model, it was found that the model was effective in illustrating mean system response characteristics.

The model was used to examine the effect of raising the crest level, and hence enhancing the storage capacity, of two of the larger tanks in the system in terms of irrigated area. The model was also used to predict what would happen if the storage of two of the tanks was combined into one. The results of the analyses indicated that all three of the interventions would pay off in wet years. It also showed that it is important to consider the water management of all tanks in the cascade together when considering changes in the structural arrangement or water management of the tanks.

The significance of the study as described in the paper is not so much in the outcome of these particular modelling exercises but in that it points the way fowards a sound approach to Improving the management of these valuable but threatened irrigation facilities.

Jacob Kijne

Director for Research

International irrigation Management Institute 


\section{Water Balance Model for Planning Rehabilitation of a Tank Cascade Irrigation System in Sri Lanka}

\section{INTRODUCTION}

The two seasons of Sri Lanka are strongly influenced by the monsoon circulation (Figure 1). The maha season, from September to March, during the northeast monsoon, brings considerable rainfall over the whole of the island. The southeast monsoon brings reliable rainfall only over the southwest of the country from April through August, during the so-called yala season. Based on such a noticeable difference in the rainfall pattern, the country is divided into two zones. The wet zone is in the southwest one fourth of Sri Lanka, and the remaining three fourths of the country make up the dry zone (Figure 2).

Cultivation of rice is important in both zones; other crops that are grown include tea, rubber and coconut (Table 1). In the wet zone, two rice crops can be grown per year. In the dry zone, rainfall is less reliable but yet the dry zone has been of major importance for rice production since time immemorial and continues to be so to this day. Tank (the subcontinental term for reservoir) based irrigation has been developed over !he centuries to overcome the unreliability of rainfall. As a storage system, the tank could store catchment runoff and regulate the flow according to the crop requirements. As a result, the tank systems have increased the available water for irrigation of rice fields in the dry zone. An aerial picture of the dry zone reveals that there are hundreds of tanks of various sizes, many of which are interconnected.

Some ancient tanks were linked through long canals to form large dam-networks stretching over several river basins. More commonly, a large number of interlinked tank irrigation systems were built in small watersheds, the so-called "tank cascade system" (TCS) (Figure 3). In the small watersheds, interlinking tanks facilitated re-use of return flow from an upstream command area in the command area of the next lower tank. This practice increased the consumable fraction of water collected in the watershed.

\section{OBJECTIVES}

The effectiveness of storage-based irrigation systems was found to be such that more and more people were attracted to the command areas of the tanks and many of the systems became unsustainable over time because of overcrowding. For that reason, this study attempts to assess, the resilience of an existing TCS. To cope with the functional deterioration of TCS, a simple water balance model has been developed to examine how a TCS can be stabilized through structural modifications. 


\section{METHODOLOGY}

The system of the Thirappane Cascade (Figure 4) has been selected for this study for its typical and simple features. The system is situated in a series of small watersheds within the huge catchment of the Nachchaduwa Dam, which was constructed in ancient times. The sample TCS is only $8 \mathrm{~km}$ long from the most upstream to the most downstream tank, and there is a total of 6 small inter-linked tanks in the system. Nowadays. each tank has its own command area and no regulating tanks remain in the TCS. Tail-end parts of a command area oflen overlap the upstream parts of the next tank area (Figure 5). Tanks now store insufficient water during dry years, because of segmentation of the watershed and the decrease in catchment area of each tank in the system.

The methodology consists of three steps:

- Develop the water balance model for the TCS through calculation of the components of water balance.

* Simulate fluctuations of tank storage with the water balance model to compare the simulated and the actual water levels for validation of the model.

* Apply the model to some hypothetical cases in which the original structure of the TCS is changed to enhance the stability of the system.

\section{BASIC STRUCTURE OF THE'WATER BALANCE}

The general structure of the water balance of a TCS is given in Figure 6. The water balance of tank (i) in period (t) is equal to the inflow minus the outflow plus the change in storage in the tank. Equation 1 shows the linkage between tanks though the return flow term:

$$
Q A i_{1} t+Q B i, t+Q C i-1, t=Q D i, t+Q E i, t+Q F i, t+d S i, t
$$

where

QA is runoff flowing into the tank

$\mathrm{QB}$ is rainfall onto the tank surface

$Q C$ is return flow from the upstream tank

QD is evaporation from the water in the tank

QE is seepage and percolation losses from the tank

QF is discharge from the tank

$S$ is tank storage volume, and dS the change in volume during period $t$

i (subscript) is the tank serial number (1-6)

$\mathrm{t}$ is the time period. 
The tanks do not spill water oflen during the maha rainy season, but if they do, the quantity spilled needs to be added to the water balance equation. In that case, equation 1 is changed into:

$$
Q A i_{i} t+Q B i, t+Q C i-1, t=Q D i, t+Q E i_{1} t+Q F i, t+\underline{Q G i, t}+d S i, t \cdots \cdots(1)
$$

\section{COMPONENTS OF THE WATER BALANCE}

In sophisticated water balance models, a runoff component is included to estimate the runoff from the catchment area (QA). However, in the case of small watersheds, $\mathbf{t}$ was difficult to find sufficiently large watercourses where flow measurements could be made. The runoff model component calmot be developed without actual flow measurements and, therefore, as a stop-gap measure, the average seasonal runoff percentage (computed from flow data estimated by analyzing the water balance) was adopted. Hence:

$$
Q A=R i_{i} t * C A i * f x i-----(3)
$$

where $R$ is precipitation, $C A$, the size of the catchment and $f x$ the average seasonal runoff percentage.

Because most of the TCS were developed in small watersheds and they consist of many small tanks, the catchment area of each tank is rather small. Moreover, the areas of the TCS are flat and the tanks are shallow The tank area is therefore not negligible compared with the catchment area, as is shown in Table 2. Thus, for this study, rainfall on the tank surface (QB) is separated from runoff flow into the tank (QA).

$$
Q B=R i, t * \text { WAi,t - - --- (4) }
$$

where WA is the surface area of the tank.

The return flow from the upstream tank is important in the water balance of a TCS. but its dependence on topography, soil moisture, daily water management of the upstream tank, etc. is too complicated to model. It was therefore assumed that the return flow flows only into the next tank downstream in a constant ratio. $\mathrm{fz}$. $\mathrm{QC}$ was also taken as a linear function of $\mathrm{QE}+\mathbf{Q F}$.

$$
Q C i, t=\langle Q E i, t+Q F i, t\rangle * f z i \cdots \cdots(5)
$$

where $\mathrm{f} z$ is the average relum flow ratio

The evaporation loss from the tank surface area, $Q D$, is given by the following equation:

$$
\text { QDi,t }=\text { Epi,t * WAi,t * dt } \cdots \cdots
$$

where Ep is evaporation from the tank, and $\mathbf{d t}$ the time period. 
The losses, QE, refer to seepage through the tank embankment and peroolation through the bed. Seepage and percolation depend on the water ievei in the tank, but here it is assumed that the loss ratio, fy, is a linear function of the tank surface area, as these tanks are quite shallow.

$$
Q E=f y i * \text { WAi,t * dt -...-.- (7) }
$$

where fy is the seepage and percolation ratio.

QF is the water supply released through the tank outlets within a specified time period.

\section{CALCULATION OF THE TERMS OF THE WATER BALANCE}

The water balance for the sample TCS required data on precipitation (R), pan evaporation (Ep). tank discharge (QF), and tank storage (S). These data were collected during two years. Values of QB, QD, $\mathrm{QF}$, and dS were calculated. The tank water surface area, WA, was obtained from the water level through a rating curve relating surface area and water level.

The terms $Q A, Q C, Q E$, and the coefficients $f x_{1} f y$, and $f z$ were arrived at through an iterative process. The first step involved the calculation of QE for the uppermost tank for which $\mathrm{QC}$ is nil. The calculation was done for a prolonged dry period for which also QA was equal to zero. The coefficient fy was then evaluated from equation 7 . The same value of fy was used for the other tanks, and their QC values were then calculated. This, in turn, made it possible to compute $Q E$ and hence $f z$ for each tank from equation 5 . These QA values were calculated for rainy periods and the average fx for each maha season and yala season was found from equation 3 .

When the tank was filled to the brim and spilling occurred, two unknowns, QA and QG. remain to be solved. In the case of spilling, the $f x$ value of the preceding period was used for the calculation of QA. Once QA is known, QG could be calculated. The effect of spilling due to large amounts of runoff in a particular period was sometimes observed to carry over into the next period although no further rainfall had occurred. For the occurrence of spilling, equation 5 had to be modified as follows:

$$
Q C i, t=(Q E i, t+Q F i, t) \cdot f z i+Q G i, t \ldots . . . .(5)
$$

The length of the period was taken as 5 or 6 days. Shorter periods were not justified considering the measurement error in reading the staff gauges.

\section{DESCRIPTION OF THE STUDY AREA}

The six tanks in the Thirappane Cascade do not form a single cascade, but there are four tanks on the main branch of the cascade and two more on a tributary branch. The main cascade, as shown in Figure 4, consists of the Vendarankulama, Meegassagama, Aiisthana, and Thirappane tanks. The two on the tributary branch, Badugama and Bulankulama, are much smaller than the other four. The main land use types in the catchment of this TCS are shown in Figure 5. The command areas of Vendarankulama and Bulankulama are joined, creating opportunities for water transfer between them. Drainage water from the Vendarankuiama command area can be used by Buiankulama farmers.

Surveys of the command areas were carried out in 1992 (Figures 7-12). A command area varies from one season to another (Table 7). As mentioned before, the lower part of the command area of one 
tank runs into the surface area of the next tank because of pressure on the land (Figure 5). The fields are generally quite small, less than 0.05 hectare (ha).

Aerial photographs of the catchment areas were taken in 1982. The command areas are given in Table 8. Part of the catchment is covered by forest, but the forested area has been decreasing due to slash and burn cultivation. To arrest deforestation, tree planting projects have been introduced in the area. Rating curves of the tanks were based on tank bed surveys carried out in 1992 . In the main cascade, tank size increases downstream (Table 9).

With respect to irrigation construction and management, the area is under the jurisdiction of the Department of Agrarian Services (DAS). which is responsible for minor irrigation works in systems with command areas of less than 80 ha. The total irrigated area of each tank is planned at the beginning of each season during farmers' meetings in the presence of officers of DAS. Each tank community conducts ils own meeting. Otheiwise. the systems of this TCS are owned and managed by the farmers. Formerly DAS was a central government department but, in recent years, its functions have been transferred to the provincial government and, more recently, to the Divisional Secretariat in Thirappane.

Rice is the dominant crop during maha with some other field crops, such as chili and soybean, on upland fields. During yala, the proportion of field crops is higher than in maha because of water shortage. The proportion of cash crops has been increasing recently with an increase of privately owned wells. The rice cultivation calendar is given in Figure 13. Direct seeding of rice is widely practiced although DAS favors transplanting to intensify cultivation.

Figure 14 presents a simplified picture of the water delivery system. There are two types of outlets from the tank, "tower outlet" and sluice gate. The tower outlet is used in the smallest tanks and allows water to flow from a hollow tower consisting of rings: as the water level rises or falls, the operator can add or remove rings to keep the tower top close to the water level, but no other control is possible. On the larger tanks, various sluice gates are used.

Rotational delivery of water to several blocks is often intended but it is poorly implemented because of inadequate infrastructure. in some cases, main canals are provided with cross-regulators. As shown in Figure 14, plot-to-plot irrigation takes place through temporary watercourses. The drainage arrangements are often not clear. Farmers sometimes obstruct the drainage flows to irrigate fields not reached by the irrigation water.

Small tractors are used for land preparation, which nevertheless usually takes over 30 days to complete in maha contrary to the official standard of $\mathbf{1 5}$ days. Farmers are anxious to frish the work as early as possible to make it possible to complete harvesting before the April rains. The main soil type in the area is low-humic grey soil, which is of low permeability. The standard irrigation interval is 7 days and the average application is $75 \mathrm{~mm}$.

\section{DATA COLLECTION}

The schedule of data collection in the sample area is shown in Figure 15. Data were collected from the middle of November 1991. Staff gauges were installed in all tanks to monitor changes in water level. Five rain gauges were installed in the sample area. Thirteen Parshall flumes were installed at the outlets to the command areas. One evaporation pan $(120 \mathrm{~cm}$ in diameter) was located near the right bank of Meegassagama. The evaporation value obtained here was used for the tank evaporation in equation 6. 


\section{DATA ANALYSIS}

The storage, rainfall and tank discharge for five tanks are presented in Figures 16-20. Spilling from all tanks occurred on 30 December 1991. In mid-January, the rains suddenly stopped and a long dry spell continued until mid-April. During this period, runoff into the tanks almost stopped while tank discharge rose to compensate for the lack of rain. Tank storage dropped sharply as outflow exceeded inflow. In mid-March, the maha irrigation season was virtually over. Tank discharge declined, and the rate of decline in water storage slowed considerably.

Rainfall returned in mid-April and water volumes in the tanks rose again. However, it did not reach a sufficient level as runoff had decreased markedly during the long dry speli. Consequently, in'most command areas, farmers were obliged to sharply reduce the areas under irrigation (Table 7). The rate of decline in water storage was much less than during the dry spell of maha as a result of the smaller irrigated areas. With the start of the rainy season in October, most of the rain infiltrated to increase soil water content and hence runoff remained small. The volumes of water stored in the tanks rose only slowly until early November. Spilling did not occur during this second maha season as the rainy season was shorter and rainfall intensity less than the year before. Discharges from the tanks are given in Table ID. Because of the lower discharges, the cultivated areas in four of the command areas were also less than those for the year before (Table 7). Farmers tried to cope with the situation by planting shortterm varieties of rice, and as some circumstantial evidence shows, by paying more attention to daily water management. As in the previous maha, rains ceased in January. Although there continued to be a few showers, tank storage showed the same trend as before but the dead storage volume was reached nearly one month earlier than in the first year of observations.

Precipitation during the initial stage of yala was also less than that in the previous yala season (Table 12). Water storage in most of the tanks hardly responded to the rains due to the markedly lower runoff. Because of the low water levels at the end of April, rice cultivation in 1993 yala was abandoned in all the command areas.

\section{COMPUTATION OF THE COEFFICIENTS}

As indicated before, the average fy value was obtained from the water balance of the Vendarankulama tank. The values were $4.7 \mathrm{~mm} /$ day in the 1991192 maha and $4.8 \mathrm{~mm} /$ day in the 1992/93 maha. Considering that the dry spell was longer and not interrupted by any showers, $4.7 \mathrm{~mm} /$ day has been used for fy throughout the model. The $f z$ value of yala was taken as zero because both $Q E$ and $Q F$ were small during this season. The $\mathrm{fz}$ values for maha for the other tanks are given in Table 13. The $\mathrm{fz}$ of Bulankulama could not be determined because it was not possible to measure QF for this tank.

The values of $\mathrm{fx}$ are given in Table 14. The values show a consistent difference between maha and yala and between the two years of observations.

\section{SIMULATIONS OF THE WATER BALANCE}

Simulations of the water balance were carried out according to the format of Table 15. Although the time span of the water balance analyses was five or six days, simulations were run with a one-day time 
period. The tank rating curves (relating volume of storage with water level height) are presented in Figure 21.

First, tank storage was simulated for the existing conditions. Comparison between actual and simulated storage assesses the validity of the model (Figures 22 and 23 ). As can be seen from the graphs, the difference between simulated storage and actual storage was greater during rainy periods than during dry spells, and greater during the first year than the second year. This is due to the inherent weakness of the simple runoff model used in the water balance model. However, the agreement was obviously sufficient to use the model for the assessment of management changes. (See Annex 2 for a more detailed analysis of the simulation model.)

Three simulations are reported here. The first deals with the possibility of raising the crest level of the Meegassagama tank in order to enhance its storage capacity. Spilling of water occurred in all tanks during the 1991/92 maha season, which indicates that there could be scope for increasing tank storage capacities. The simulation was carried out with the first year's data, subject to the following conditions:

* Raising the crest level of the Meegassagama tank should not diminish the storage achieved in the other tanks.

* Discharge QF should increase at the same rate as extension of the command area.

- Extension of the command area is limited only during maha.

- Simulated storage should not decrease below actual storage at the end of March.

The results of the simulation are shown in Figure 24. It is shown that the crest level could be raised by about $60 \mathrm{~cm}$ without adversely affecting storage in the other tanks of the cascade. The concurrent increase in command area of Meegassagama tank is 39 ha.

The second simulation involved the possibility of enhancing storage in the Alisthana tank, also based on the first year's data and subject to the same set of conditions as in the first simulation. The results are shown in Figure 25. It was found that the crest level could be raised by about $30 \mathrm{~cm}$, increasing the command area by 16 ha, without affecting storage in the other tanks of the cascade.

The third simulation examines the possibility of combining the Vendarankulama and the Meegassagama tanks, based on the second year's data. Peak storage in all tanks was extremely low during the second maha season, but especially in small tanks such as Vendarankularna and Bulankulama. In these two tanks, storage was reduced to the dead storage before the end of February. Subsuming the storage of Vendarankulama in Meegassagama could result in slowing the rate of decrease in storage and hence of abandoning farm land for lack of water in late yala. Costs of operation and maintenance would also be reduced. The simulation was carried out subject to the following conditions.

* Simulated tank storage should not decrease below actual storage at the end of March

* Discharge from the tank should increase at the same rate as extension in command area

The results are presented in Figure 26. Only 4 ha of the combined command areas of the two tanks was lost although the reuse of return flow was markedly reduced. 


\section{CONCLUSIONS}

It was shown in the paper that the simple water balance model applied to the sample tank cascade can help to assess possible improvements in managing water that aim to enhance the usable fraction of rainfall in the catchment area. It was found to be important to consider the water management of all tanks of a cascade together in an integrated manner.

The water balance model, certainly if a more satisfactory rainfall-runoff model is incorporated, is a useful decision support tool to be used in operating tank cascades optimally. The type of analysis described in the paper would also help in identifying which tanks should be rehabilitated in a rehabilitation program, and what kind of changes to make. 
Figure 1. Monsoon circulation.
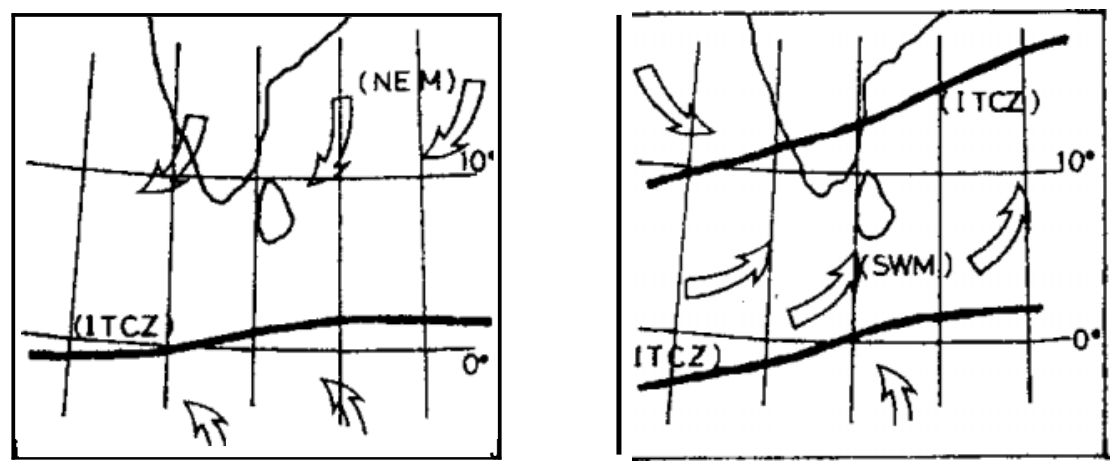

ITCZ = Inter-Tropical Convergence Zone

NEM = Northeast Monsoon (October - February; corresponds to the maha season) SWM = Southwest Monsoon (May - September corresponds to the yala season)

Figure 2. Dry and wet zones of Sri Lanka.

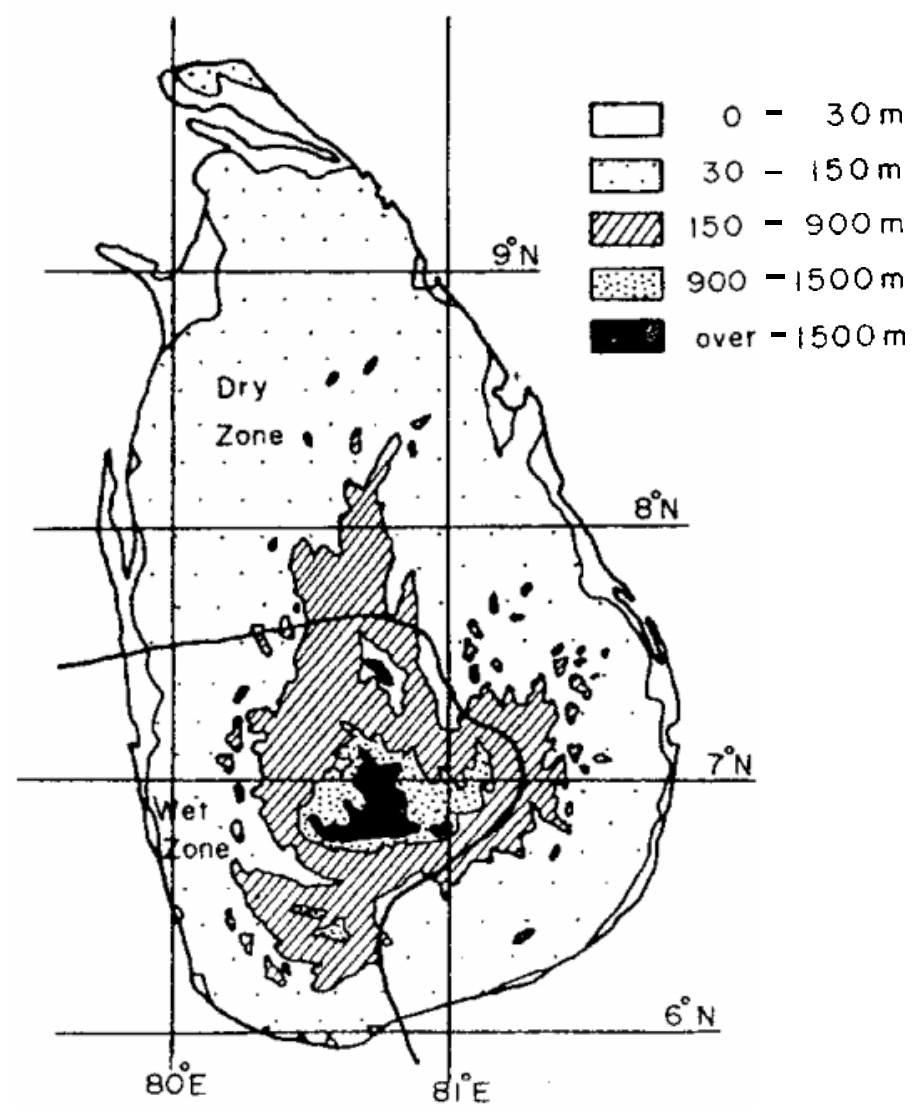


Figure 3. Tank cascade imigation system.
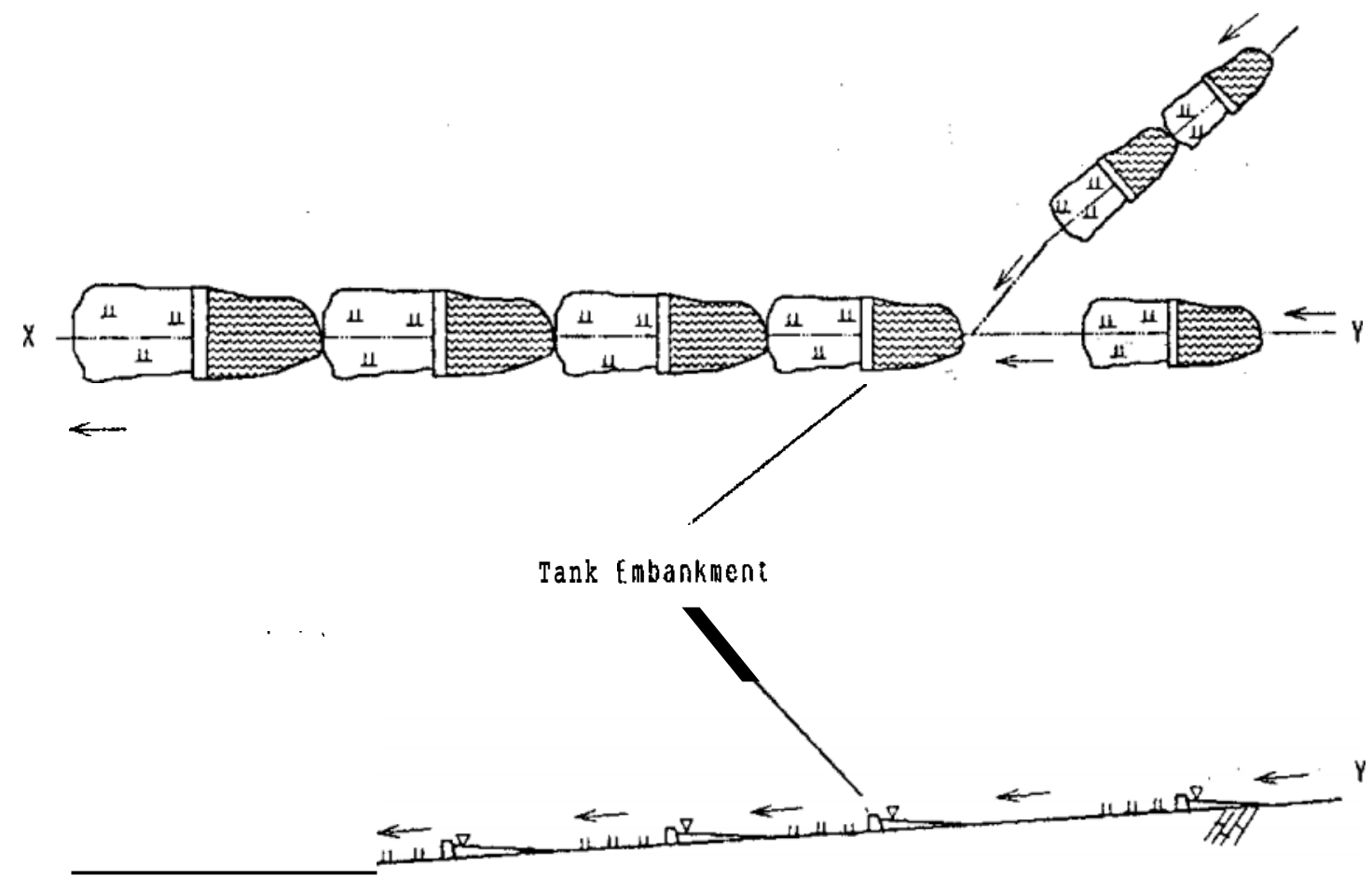

(rey)

$\leftarrow$

Flow Direction

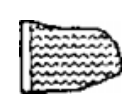

Tank

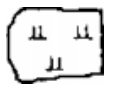

Paddv Field 
Figure 4. Nachchaduwa Dam and neighbouring tank cascade systems.

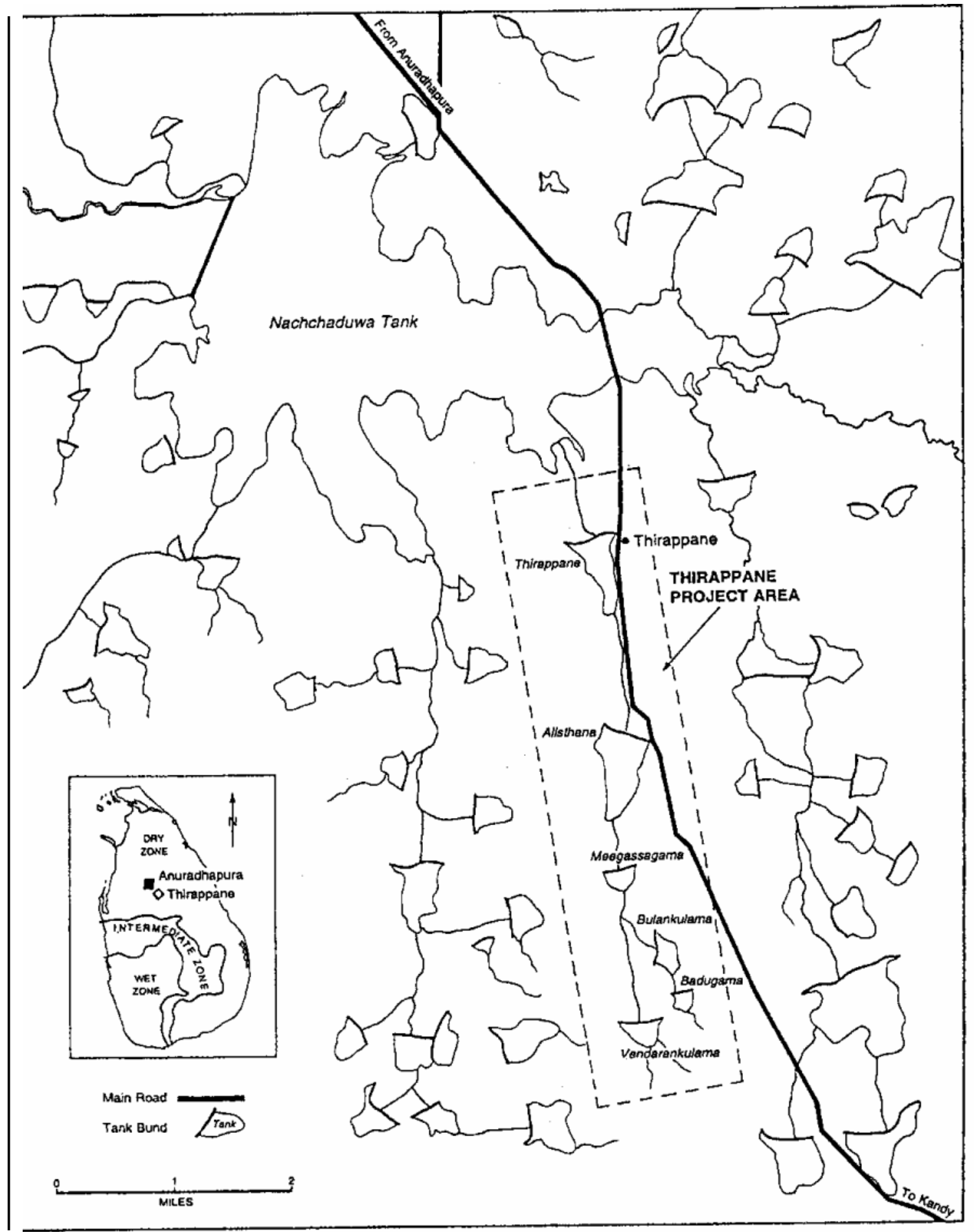


Figure 5. Land use in catchment of Thirappane Cascade.

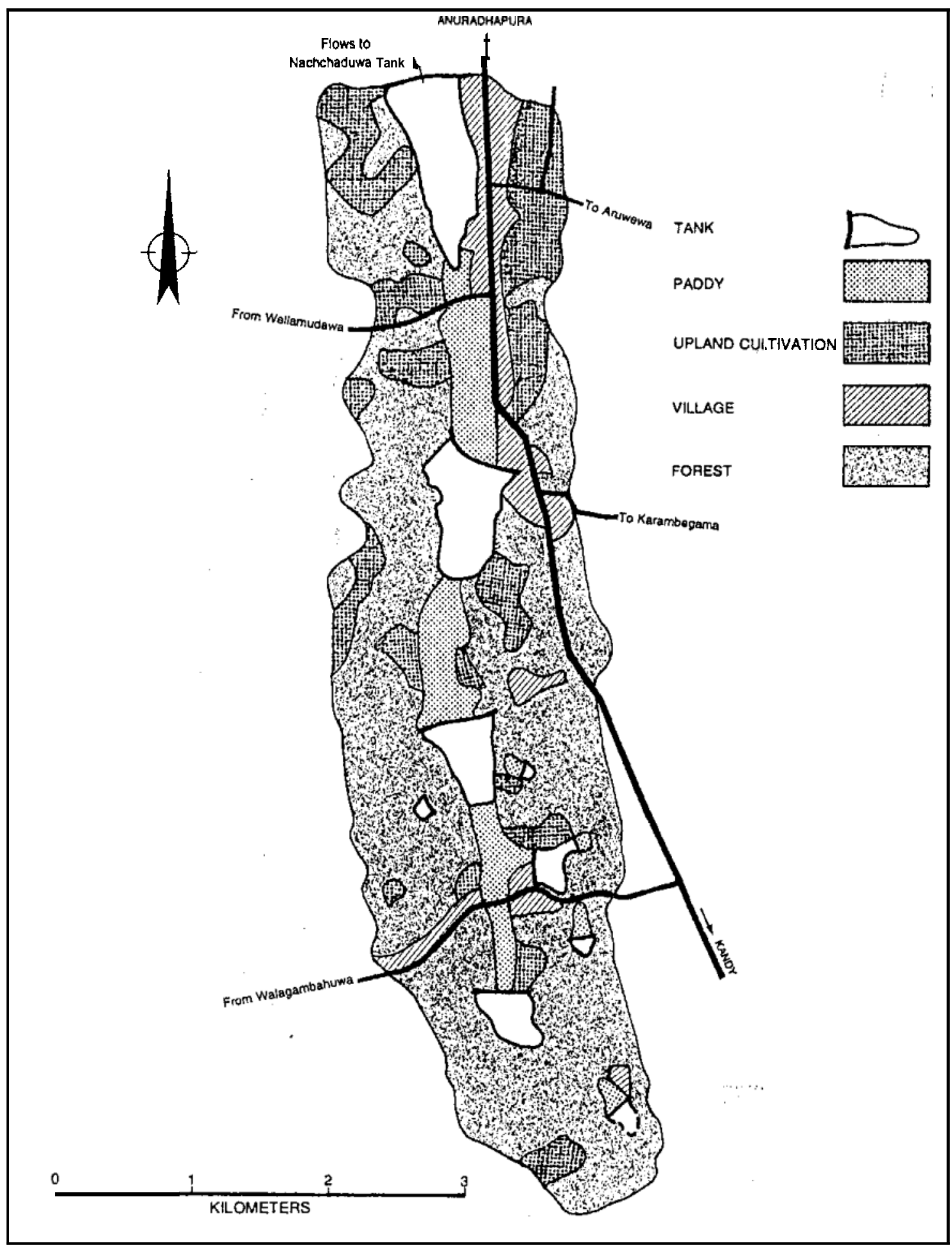


Figure 6. Structure of water balance model.




Figure 7. Command area of Vendarankulama Tank.

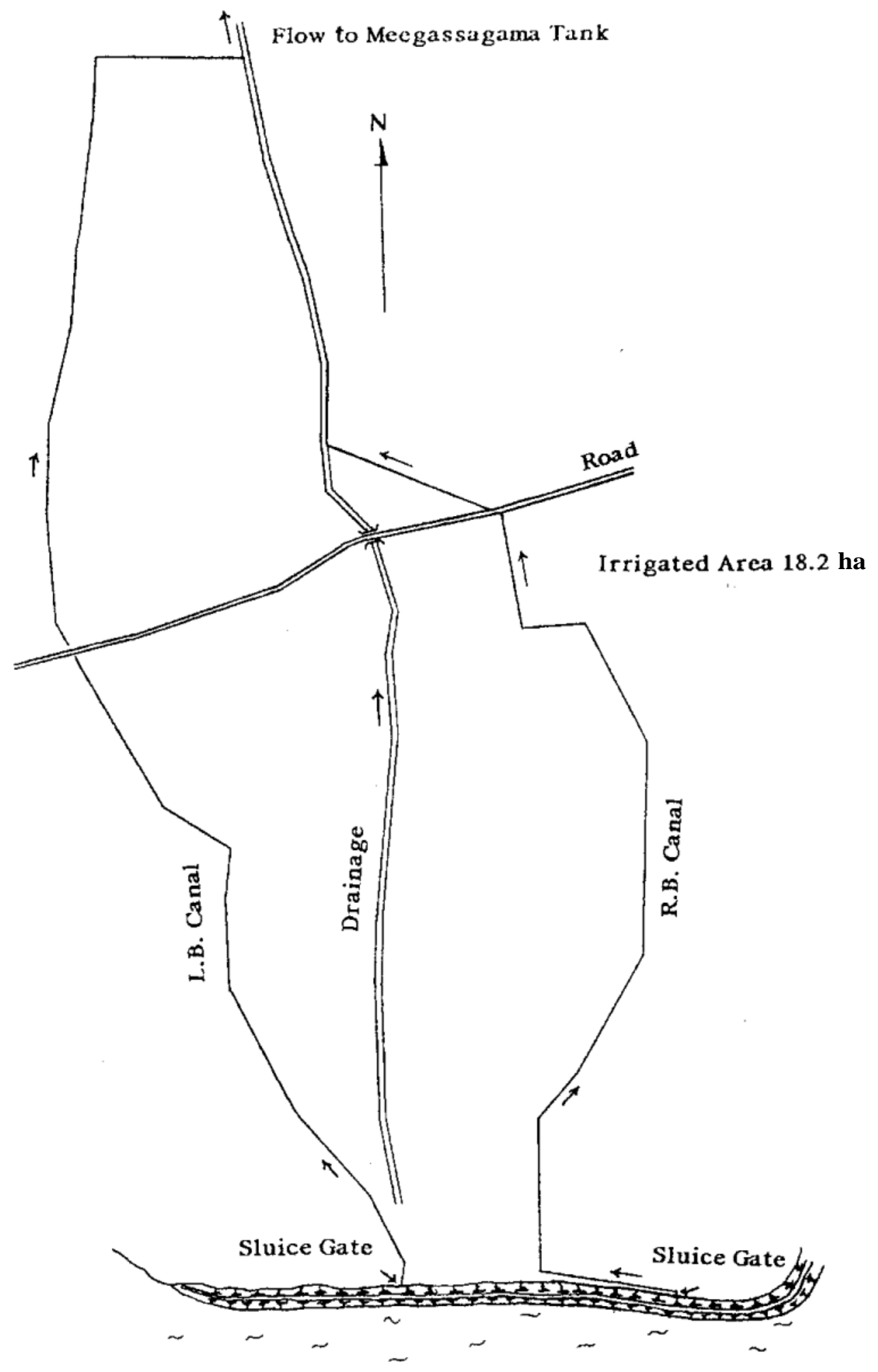


Figure 8. Command area of Meegassagama Tank.

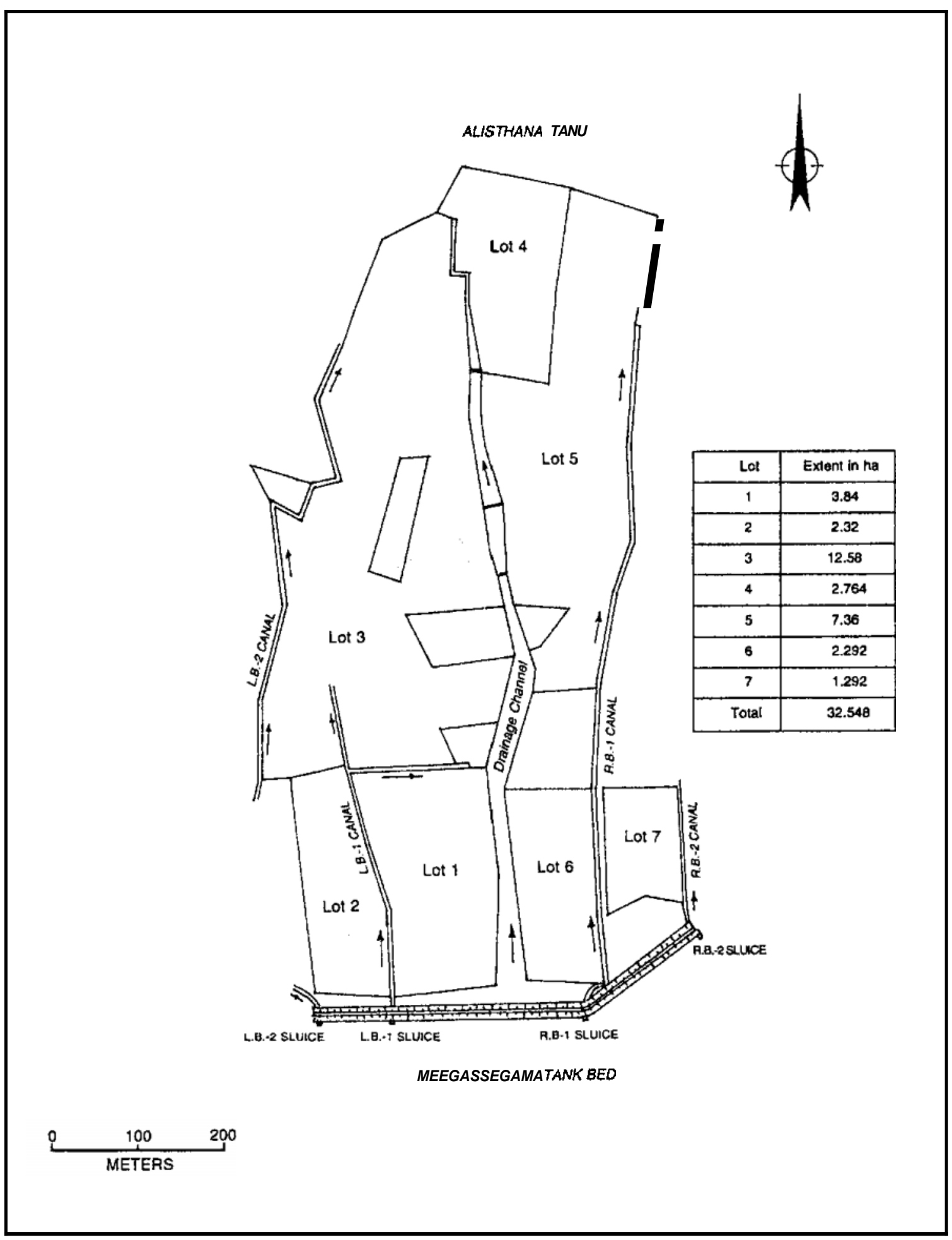


Figure 9. Command area of Alisthana Tank.

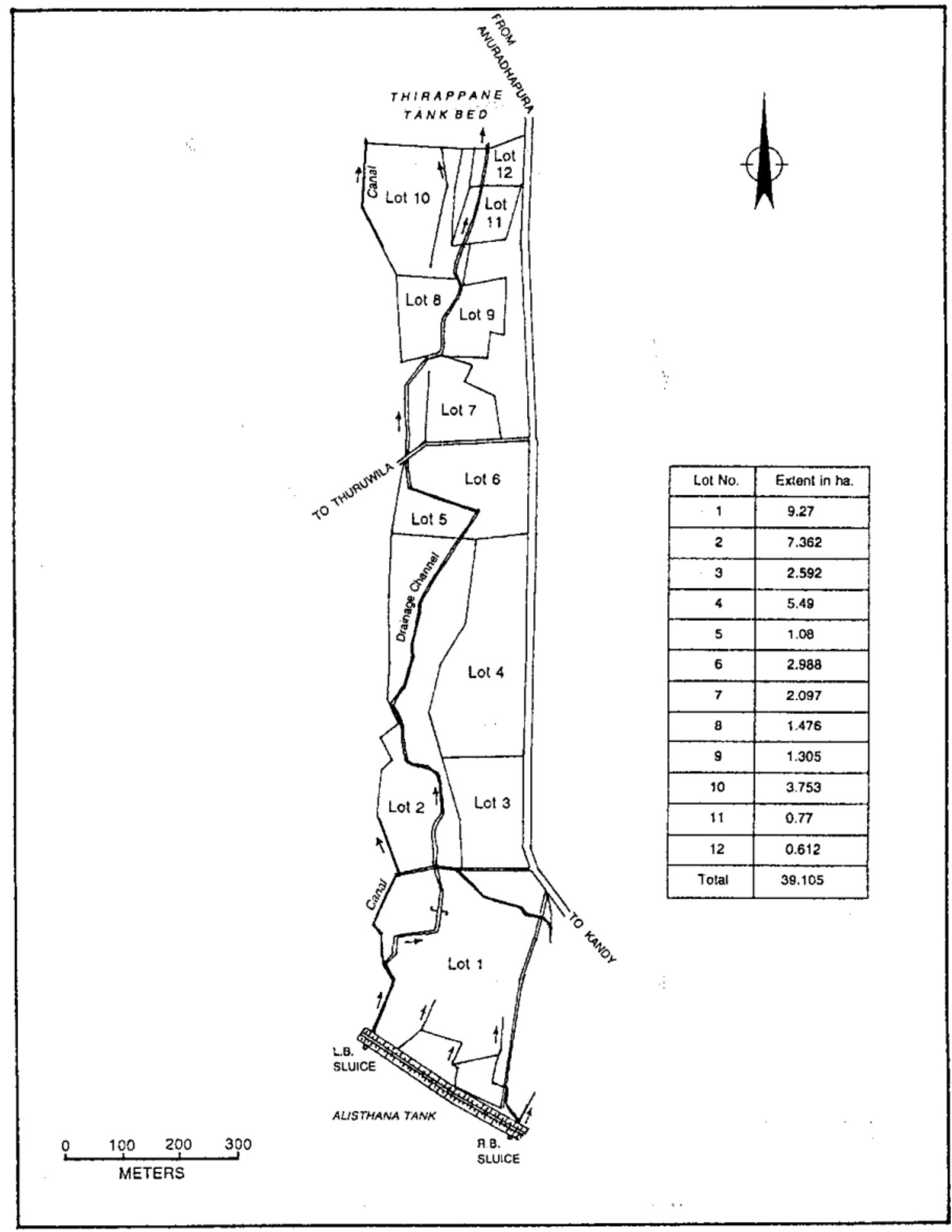


Figure 10. Command area of Thirappane Tank.

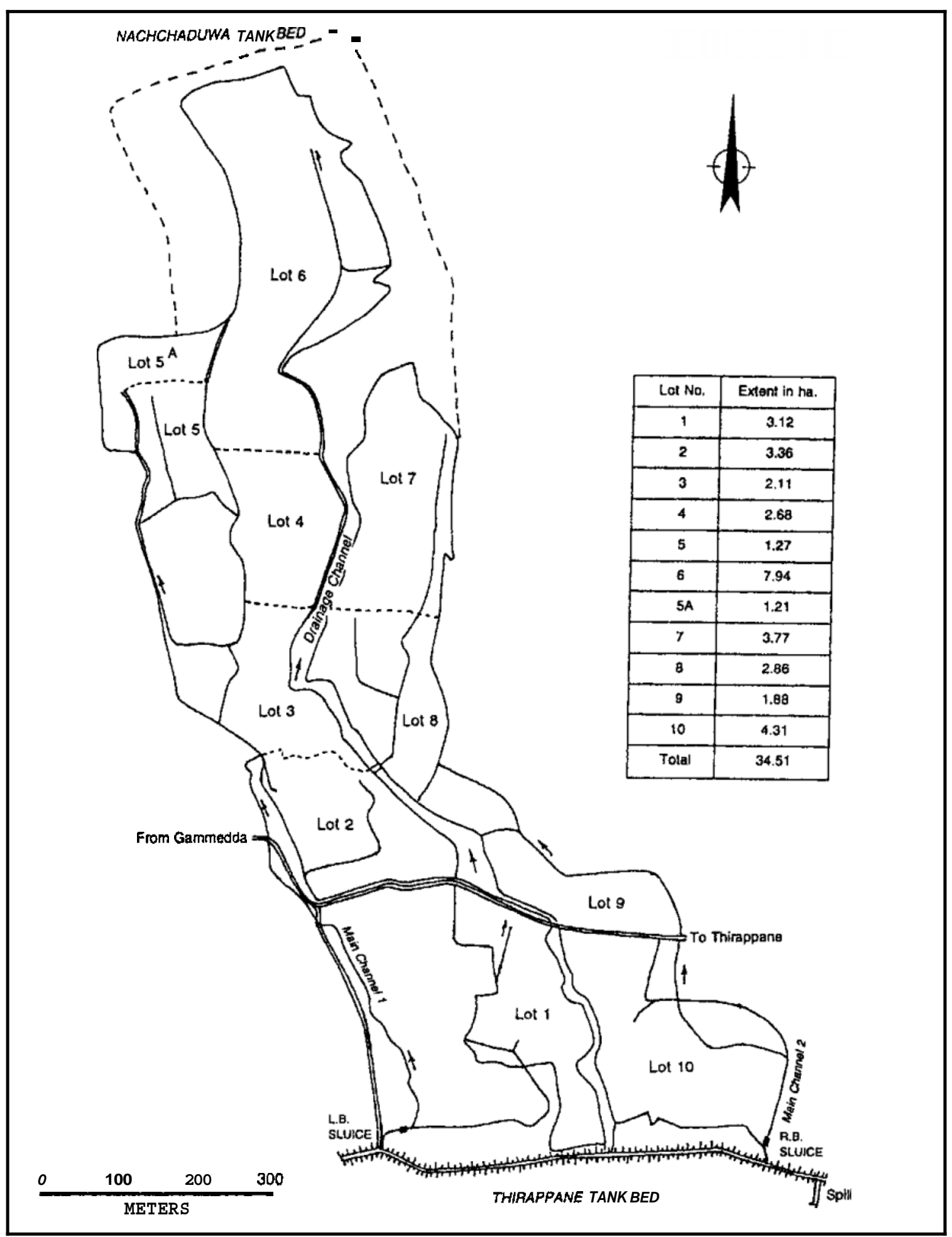


Figure 11. Command area of Badugama Tank.

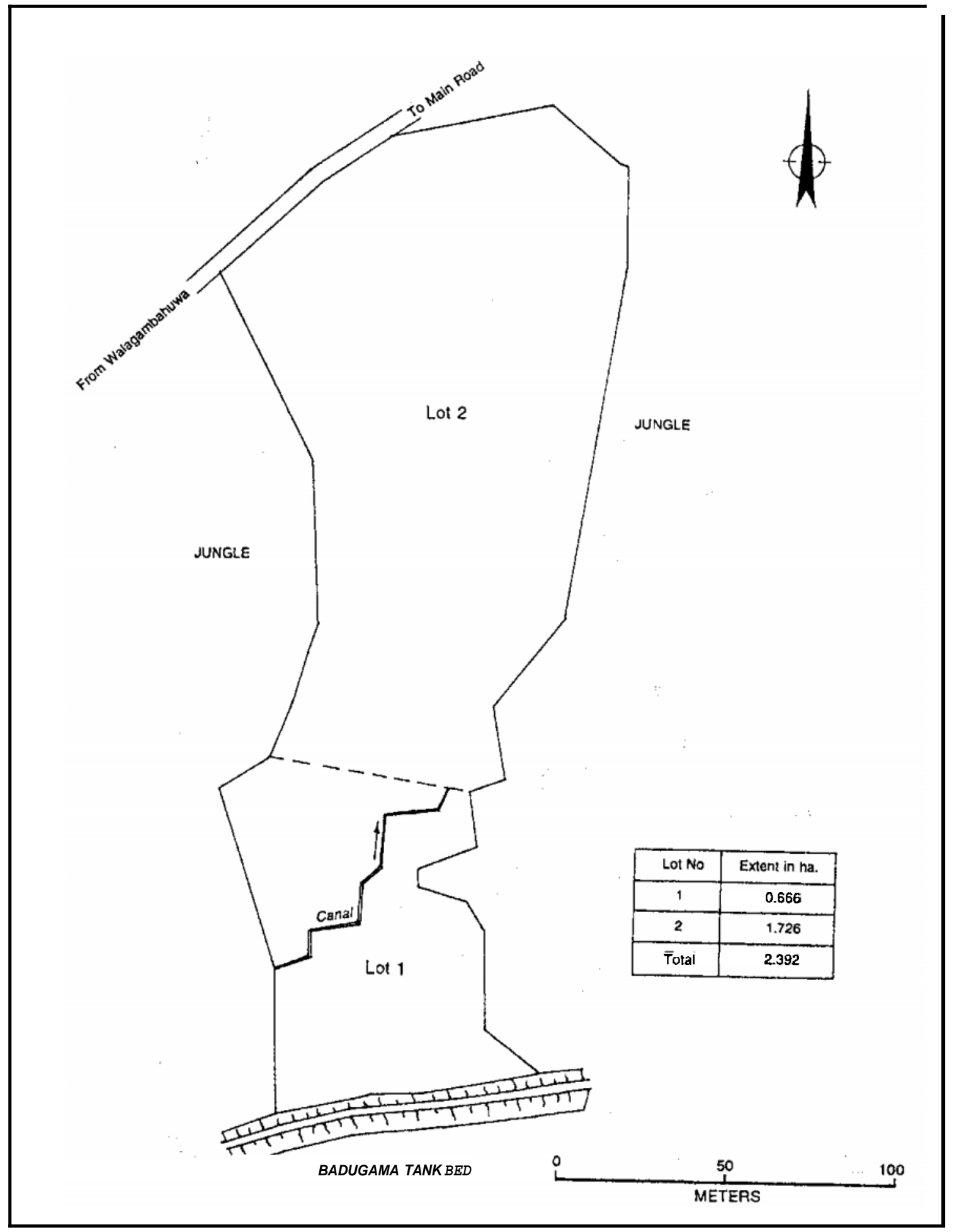

